\title{
STATUS GIZI DAN HUBUNGANNYA DENGAN GANGGUAN MENSTRUASI PADA PETANI TEMBAKAU DI DESA AMBULU, KECAMATAN AMBULU, JEMBER
}

\author{
Indriyanti \\ Fakultas Kesehatan Masyarakat, Universitas Airlangga \\ Email: indriyaln@gmail.com
}

\begin{abstract}
Menstrual disorders can be a sign of an illness or an abnormal hormonal system. The presence of hormonal abnormalities in a woman's body can be caused due to nutritional status. The purpose of this study was to analyze the relationship between nutritional status and menstrual disorders in tobacco farmers in Ambulu Village. The population in this study were female workers on tobacco farming in Ambulu village, Ambulu Subdistrict, Jember Regency with 39 workers. The number of research samples is taken from the entire population. The dependent variable in this study is nutritional status, and the independent variables are menstrual disorders. Based on research, it can be concluded that there is a relationship between nutritional status and menstrual disorders. as many as 26 people (66.7\%). From the assessment of nutritional status, the results of the majority of respondents with abnormal nutritional status, both underweight and overweight, were as many as 20 people (51.2\%). From the results of the statistical test, the value of the contingency coefficient is 0.436. It was concluded that the strong relationship between nutritional status and menstrual disorders in tobacco farmers in Ambulu Village, Jember Regency was included in the moderate level.
\end{abstract}

Keywords: Menstrual Disorders, Nutritional Status, Tobacco Farmer

\begin{abstract}
ABSTRAK
Gangguan mentruasi dapat menjadi pertanda adanya penyakit ataupun adanya sistem hormon yang tidak normal. Adanya danya ketidaknormalan hormon pada tubuh wanita dapat disebabkan karena status gizi. Tujuan penelitian ini untuk menganalisis hubungan antara status gizi dan gangguan menstruasi pada petani tembakau di Desa Ambulu. Populasi pada penelitian ini adalah pekerja wanita di pertanian tembakau desa Ambulu, Kecamatan Ambulu, Kabupaten Jember sejumlah 39 pekerja. Jumlah sampel penelitian diambil dari seluruh jumlah populasi yang ada. Variabel dependen pada penelitian ini adalah status gizi, dan varibel independennya adalah gangguan menstruasi. Berdasarkan penelitian, dapat disimpulkan terdapat hubungan antara status gizi dengan gangguan menstruasi. sebanyak 26 orang (66,7\%). Dari penilain status gizi diperoleh hasil sebagian besar responden berstatus gizi abnormal, baik underweight maupun overweight yaitu sebanyak 20 orang $(51,2 \%)$. Dari hasil uji statistik diperoleh nilai koefisien kontingensi yaitu 0,436. disimpulkan bahwa kuat hubungan antara status gizi dengan gangguan menstruasi pada petani tembakau di Desa Ambulu, Kabupaten Jember termasuk dalam tingkat sedang.
\end{abstract}

Kata kunci: Gangguan Menstruasi, Status Gizi, Petani Tembakau 


\section{PENDAHULUAN}

Saat ini wanita yang terjun pada sektor dunia kerja semakin mudah dijumpai. Berdasarkan data yang dikeluarkan Badan Pusar Statistik diketahui jumlah pekerja wanita mengalami peningkatan setiap tahunnya yaitu mencapai 50\% lebih tinggi dibandingkan dengan jumlah pekerja laki-laki. Pada Survei Angkatan Kerja Nasional yang dilakukan BPS pada tahun 2016 menyebutkan jumlah wanita bekerja sekitar 45,5 juta dimana sektor pertanian, kehutanan, dan perikanan merupakan sektor yang banyak menyerap tenaga kerja wanita. ${ }^{1}$

Data dari Badan Pusat Statistik Provinsi Jawa Timur diketahui bahwa jumlah tenaga kerja di Kabupaten Jember adalah 43.031 tenaga kerja, dimana 20.467 diantaranya adalah pekerja wanita. Daerah ini merupakan salah satu daerah pertanian dan penghasil tembakau dengan hasil produk tembakau yang berkualitas. Tanaman tembakau menjadi komoditi unggulan di kabupaten ini Berdasarkan data Badan Pusat Statistik Provinsi Jawa Timur tahun 2014, diketahui bahwa luas lahan pertanian tembakau di kabupaten ini semakin banyak setiap tahunnya, dimana pada tahun 2006-2013 terdapat peningkatan luas lahan pertanian tembakau di Kabupaten Jember. $^{2}$

Keikutsertaan wanita pada sektor dunia kerja khususnya sektor pertanian menyiratkan status kesetaraan gender yang memposisikan wanita dipandang mampu untuk melakukan pekerjaan seperti laki-laki, sehingga pekerja wanita juga memiliki hak untuk memperoleh perlindungan baik sosial, ekonomi, ataupun yang lainnya. Meskipun demikian perempuan secara kodrati memiliki perbedaan dengan lakilaki secara fisik dan biologis, sehingga dibutuhkan pengecualian terhadap kondisi tertentu pada pekerja wanita, seperti pada kondisi kehamilan, persalinan, masa nifas, menyusui, ataupun pada kondisi kesehatan reproduksi lainnya. ${ }^{3}$

Menurut WHO dan ICPD (International conference on Population and Development) 1994 yang diselenggarakan di Kairo, kesehatan reproduksi adalah keadaan sehat yang menyeluruh, meliputi aspek fisik, mental dan sosial. Bukan hanya sekedar tidak adanya penyakit atau gangguan segala hal yang berkaitan dengan sistem reproduksi, fungsinya maupun proses reproduksi itu sendiri. Secara umum, masalah kesehatan reproduksi pada wanita dapat berupa gangguan mentruasi, infertilitas, infeksi penyakit menular, menopause, dan lain-lain. ${ }^{4}$

Salah satu proses fisiologi pada wanita yang berbeda dengan laki-laki adalah proses menstruasi. Menstruasi merupakan perdarahan secara periodik yang dialami oleh wanita pada siklus reproduksinya yang dimulai dari menarche. ${ }^{5}$ Mentruasi yang normal sangat penting untuk mengetahui kesuburan, konsepsi, ataupun gangguan infertilitas pada wanita. Pada 
proses menstruasi dapat terjadi beberapa gangguan yang dinamakan gangguan mentruasi (menstrual disorder). Gangguan mentruasi tersebut seperti dismenorea, amenorea, polimenorea, oligomenorea, hipermenorea, hipomenorea, dan metrorargia. ${ }^{4}$

Gangguan menstruasi merupakan keluhan yang sering menyebabkan wanita datang berobat ke dokter atau tempat pertolongan pertama. Keluhan pada gangguan menstruasi ini bervariasi dari yang ringan hingga berat, dan tidak jarang menimbulkan rasa frustasi bagi penderitanya. Data di beberapa negara industri menyebutkan bahwa seperempat penduduk perempuan dilaporkan pernah mengalami menoragia atau hipermenorea, 21\% mengeluh siklus haid memendek, $17 \%$ mengalami metrorargia, dan 6\% mengeluh perdarahan pasca senggama. Selain menyebabkan gangguan kesehatan, gangguan menstruasi juga berpengaruh pada aktivitas sehari-hari yaitu sebanyak $28 \%$ dilaporkan merasa terganggu saat bekerja sehingga hal ini dapat berdampak pada bidang ekonomi. ${ }^{4}$

Lindbohm (1995) dalam penelitian Soyameh menyatakan bahwa paparan bahan organik di tempat kerja diketahui berhubungan dengan gangguan kesehatan reproduksi, seperti gangguan menstruasi dan gangguan fertilitas yang berefek terhadap kehamilan. Dari penelitian ini diketahui terdapat hubungan antara paparan pelarut organik dengan peningkatan gangguan menstruasi dan perubah- an hormon pada tenaga kerja wanita. Pada penelitian ini, usia pekerja, usia saat menarche, indeks massa tubuh, olahraga, stres kerja, dan shift kerja juga menjadi faktor signifikan terjadinya gangguan menstruasi pada pekerja wanita. 6

\section{Penelitian Harsetianingrum (2015),} menunjukkan hasil sebagian besar tenaga kerja wanita di area finishing PT. XYZ Sidoarjo mengalami gangguan menstruasi. Pada penelitian ini diketahui bahwa ada hubungan antara karakteristik individu yaitu status gizi, umur saat menarche, jumlah partus, dan pemakaian kontrasepsi dengan gangguan menstruasi pada tenaga kerja wanita. $^{7}$ Penelitian Novita (2018), diketahui sebanyak $60,20 \%$ remaja putri mengalami gangguan menstruasi dan sebagian besar mengalami gangguan berupa premenstrual syndrome dan dismenorea. Dari uji statistik diketahui bahwa status gizi kurang memiliki hubungan yang bermakna dengan gangguan mentruasi pada responden (nilai $\mathrm{p}=0,035){ }^{8}$

Status gizi merupakan keadaan tubuh individu karena adanya konsumsi dan penggunaan zat-zat di dalamnya. Asupan gizi yang berlebih ataupun kurang dapat menyebabkan terjadinya gangguan pada siklus menstruasi, seperti asupan karbohidrat, protein, dan lemak yang berperan penting pada fase selama menstruasi. ${ }^{9}$

Menurut Su'mamur (2009) tenaga kerja wanita memiliki perbedaan dengan pekerja 
pria, yang dapat dilihat dari perbedaan fisik dan biologisnya meliputi kehamilan, melahirkan, menopause, menstruasi, dan lain-lain. Serta perbedaan pada sosial kultural dimana seorang wanita memiliki peran ganda sebagai seorang ibu dan sumber daya dalam pekerjaan. ${ }^{3}$

Tenaga kerja wanita pada sektor formal seperti industri dan perkantoran yang mengalami gangguan menstruasi dapat menyebabkan kinerja menurun sehingga penurunan produktivitas kerja dapat terjadi. Hal ini disebabkan karena semakin sering gangguan kesehatan reproduksi dialami oleh tenaga kerja wanita, maka tingkat ketidakhadiran bekerja juga akan semakin tinggi. Penelitian mengenai gangguan menstruasi pada pekerja wanita di bidang informal masih jarang dilakukan sehingga perlu dilakukan penelitian untuk melihat bagaimana gambaran gangguan menstruasi pada pekerja wanita di sektor informal.

Dari hasil wawancara tidak terstruktur dengan petani wanita di pertanian tembakau di Desa Ambulu, Kabupaten Jember, diketahui bahwa beberapa pekerja pernah mengalami gangguan kesehatan repoduksi, berupa siklus mentruasi yang panjang, rasa lelah yang berlebih saat bekerja jika dalam keadaan mentruasi, dan beberapa dari mereka terkadang tetap bekerja walaupun dalam kondisi tersebut. Hal ini dapat merugikan pekerja wanita, karena dapat menurunkan performa kerja dan produk - tivitas kerja. Oleh karena itu, peneliti tertarik untuk melihat gambaran gangguan mentruasi pada petani wanita di pertanian tembakau Desa Ambulu, serta menganalisis hubungan status gizi dengan gangguan menstruasi yang terjadi pada petani tembakau.

\section{METODE PENELITIAN}

Penelitian ini merupakan jenis penelitian observasional. Berdasarkan sifat masalah dan analisis datanya termasuk jenis penelitian deskriptif. Ditinjau dari segi waktunya, penelitian ini merupakan cross sectional karena untuk mempelajari dinamika korelasi dengan cara pendekatan, observasi, dan pengumpulan data sekaligus pada suatu saat. ${ }^{10}$ Populasi pada penelitian ini adalah pekerja wanita di pertanian tembakau desa Ambulu, Kecamatan Ambulu, Kabupaten Jember sejumlah 39 pekerja. Jumlah sampel penelitian diambil dari seluruh jumlah populasi yang ada. Waktu penelitian dilakukan sejak bulan Mei hingga Agustus 2018.

Variabel pada penelitian ini terdiri dari variabel dependent yaitu ganguan menstruasi, dan variabel independent yaitu status gizi. Data diperoleh dengan cara wawancara menggunakan kuesioner, kemudian dilakukan analisis dalam bentuk tabel dan narasi yang terdiri dari analisis univariat dan bivariat. Analisis deskriptif dilakukan dengan menggunakan crosstab (tabel silang) dan pengukuran kuat hubungan variabel dilakukan dengan melihat nilai koefisien kontingensi. 


\section{HASIL DAN PEMBAHASAN}

Hasil penelitian diperoleh dengan menggunakan kuesioner yang meliputi data status gizi dan gangguan mentruasi pada petani tembakau di Desa Ambulu, Kecamatan Ambulu, Kabupaten Jember. Distribusi variabel dapat dilihat pada tabel berikut.

\section{Status Gizi}

Tabel 1. Distribusi Status Gizi Responden Petani Tembakau di Desa Ambulu, Kecamatan Ambulu, Kabupaten Jember.

\begin{tabular}{lcc}
\hline Status Gizi & $\mathrm{n}$ & $\%$ \\
\hline Underweight & 6 & 15.3 \\
Normal & 19 & 48.8 \\
Overweight & & \\
1. Beresiko & 11 & 28.2 \\
2. Obese 1 & 3 & 7.7 \\
\hline Total & 39 & 100.0
\end{tabular}

Sumber: Data Primer, 2018.

Berdasarkan Tabel 1 dapat dilihat bahwa sebagian besar responden petani tembakau di desa Ambulu, Kabupaten Jember memiliki status gizi tidak normal, baik itu kurang gizi (underweight) maupun gizi berlebih (beresiko, dan obese I) sebanyak 20 orang $(51,2 \%)$, dan responden yang berstatus gizi normal sebanyak 19 orang $(48,8 \%)$.

\section{Gangguan Menstruasi}

Tabel 2. Distribusi Gangguan Menstruasi Responden Petani Tembakau di Desa Ambulu, Kecamatan Ambulu, Kabupaten Jember.

\begin{tabular}{lcc}
\hline Gangguan Menstruasi & $\mathrm{n}$ & $\%$ \\
\hline Ada Gangguan & 26 & 66,7 \\
\hline Tidak Ada Gangguan & 13 & 33,3 \\
\hline Total & 39 & 100.0 \\
\hline
\end{tabular}

Sumber: Data Primer, 2018
Berdasarkan Tabel 2 dapat dilihat bahwa sebagian besar responden mengalami gangguan menstruasi yaitu sebanyak 26 orang $(66,7 \%)$, dan yang tidak mengalami gangguan menstruasi sebanyak 13 orang (33,3\%). Gangguan menstruasi yang dirasakan oleh responden yang dilihat dari jumlah perdarahan, siklus atau durasi, dan gangguan lain yang berhubungan dengan mentruasi. Responden dikatakan memiliki gangguan menstruasi jika mengalami salah satu gangguan dari kriteria tersebut.

\section{Hubungan Antara Status Gizi dengan Gangguan Menstruasi}

Tabel 3. Hubungan Status Gizi dengan Gangguan Menstruasi

\begin{tabular}{|c|c|c|c|}
\hline \multirow[t]{2}{*}{ Status Gizi } & \multicolumn{2}{|c|}{$\begin{array}{l}\text { Gangguan } \\
\text { Menstruasi }\end{array}$} & \multirow[t]{2}{*}{$\begin{array}{c}\text { Contingency } \\
\text { Coefficient }\end{array}$} \\
\hline & Ya & Tidak & \\
\hline Underweight & 2 & 4 & 0,436 \\
\hline Normal & 11 & 8 & \\
\hline $\begin{array}{r}\text { Overweight } \\
\text { Berisiko }\end{array}$ & 11 & 0 & \\
\hline Obese I & 2 & 1 & \\
\hline Total & 26 & 13 & \\
\hline
\end{tabular}

Sebagian besar responden mempunyai status gizi abnormal dan mengalami gangguan menstruasi sebanyak 26 orang dengan rincian responden yang tergolong mempunyai status gizi underweight $(\mathrm{IMT}<18,5)$ yang mengalami gangguan menstruasi sebanyak 2 orang, responden yang tergolong mempunyai status gizi overweight berisiko (IMT:23-24,9) yang mengalami gangguan menstruasi sebanyak 11 
orang, responden yang mempunyai status gizi overweight obese I (IMT:25-29,9) yang mengalami gangguan menstruasi sebanyak 2 orang.

Dari hasil uji statistik didapatkan nilai koefisien kontingensi 0,436. Kemudian kuat hubungan antara variabel status gizi dengan gangguan mentruasi dilihat keeratannya dengan menggunakan pedoman Sugiyono (2009). ${ }^{11}$ Hasil perhitungan koefisien kontingensi tersebut termasuk dalam kategori 0,40-0,599 dan termasuk kategori kuat hubungan yang sedang. Sehingga disimpulkan bahwa kuat hubungan antara status gizi dengan gangguan menstruasi pada petani tembakau di Desa Ambulu, Kabupaten Jember termasuk dalam tingkat sedang.

Hasil ini sejalan dengan penelitian Adnyani (2013), yaitu terdapat hubungan antara lemak tubuh dengan siklus menstruasi. ${ }^{12}$ Estrogen merupakan salah satu hormon yang berperan dalam proses menstruasi. Hormon ini disintesis di adrenal, ovarium, plasenta, jaringan lemak dan susunan saraf pusat. Jumlah estrogen yang meningkat dapat menyebabkan siklus menstruasi lebih panjang. Hormon estrogen dalam darah dapat mengalami peningkatan dikarenakan meningkatnya lemak tubuh. $^{13}$

Penelitian Novita (2017) diketahui bahwa sebagian responden yang memiliki status gizi kurang dan berlebih mengalami gangguan menstruasi berupa premenstrual syndrome dan dismenorea dan diperoleh hubungan yang bermakna antara status gizi pada remaja putri dengan gangguan menstruasi yang dialami. ${ }^{8}$ Asupan gizi yang kurang pada kebanyakan wanita umunya dipengaruhi karena pola konsumsi yang rendah zat gizinya. Sehingga hal ini akan berdampak pada gangguan haid, status gizi akan membaik bila asupan nutrisinya juga baik. ${ }^{14}$

Dari penelitian Sinha (2016) diketahui bahwa terdapat hubungan antara IMT atau Body Mass Indeks dengan gangguan menstruasi pada wanita di Bankura, India. Lemak tubuh merupakan prediktor penting terjadinya gangguan mentruasi yaitu dismenorea, karena lemak tubuh mengatur aktivitas hormon steroid yang dapat mengontrol endokrin dalam tubuh wanita. Lemak tubuh juga diperlukan untuk mempertahankan siklus ovulasi pada wanita. Sehingga, kondisi lemak tubuh yang kurang ataupun berlebih dapat mempengaruhi sistem reproduksi pada wanita. ${ }^{15}$

\section{SIMPULAN DAN SARAN}

\section{Simpulan}

Kesimpulan dari penelitian ini adalah sebagian besar petani tembakau di Desa Ambulu, Kecamatan Ambulu, Jember mengalami gangguan menstruasi yaitu sebanyak 26 orang $(66,7 \%)$. Dari penilain status gizi diperoleh hasil sebagian besar responden berstatus gizi abnormal, baik underweight maupun overweight yaitu 
sebanyak 20 orang $(51,2 \%)$. Dari hasil uji statistik diperoleh nilai koefisien kontingensi yaitu 0,436 . Sehingga disimpulkan bahwa kuat hubungan antara status gizi dengan gangguan menstruasi pada petani tembakau di Desa Ambulu, Kabupaten Jember termasuk dalam tingkat sedang.

\section{Saran}

Sebaiknya responden memperbanyak konsumsi buah dan sayur, serta asupan nutrisi yang cukup sangat diperlukan oleh pekerja. Responden juga sebaiknya mengkonsumsi air putih dalam jumlah yang cukup dan menjaga gaya hidup sehat. Bila responden mengalami gangguan mentruasi, misal seperti nyeri saat mentruasi dan rasa pusing sebaiknya melakukan istirahat sejenak, dan melakukan kompres hangat pada bagian perut. Dan jika dirasa gangguan tersebut sangat mengganggu, sebaiknya segera memeriksakan diri ke dokter.

\section{REFERENSI}

1. Badan Pusat Statistik. Tenaga Kerja (Online). https://www.bps.go.id/subject/6/ tenaga-kerja.html. Diakses online pada tanggal 26 April 2018. 2017

2. Herminingsih, H. Pengaruh Perubahan Iklim Terhadap Perilaku Petani Tembakau di Jember. Agribisnis FMIPA UPBJJ-UT Jember. 2014.

3. Suma'mur. Higiene Perusahaan dan Kesehatan Kerja (HIPERKES). Sagung Seto. 2009.

4. Sarwono. Ilmu kandungan. Edisi ke Tiga. PT Bina Pustaka Sarwono Prawirohardjo: Jakarta. 2011.

5. Harlow, S.D., Windham, G.C., \&
Paramsothy, P. Menstruation and Mentrual Disorders. i M. B. Goldman, Women and Health. California: Academic Press. 2013.

6. Soyameh, H., Namvar M., Maryam G., Mirsaeed A., Majid G., Seyedmehdi M. dan Mahshad. Menstrual Disturbance and Hormonal Changes in Woman Workers Expose to a Mixture of Organis Solvents in a Pharmaceutical Company. Medical Journal of Islamic Republic of Iran (MJIRI). 2014.

7. Harsetianingrum, R.A. Analisis Risiko Timbulnya Gangguan Menstruasi Pada Tenaga Kerja Wanita di PT. XYZ, Sidoarjo. Skripsi. Universitas Airlangga. 2015.

8. Novita, R. Hubungan Status Gizi dengan Gangguan Menstruasi pada Remaja Putri di SMA Al-Azhar Surabaya. Amerta Nutrition. 2017.

9. Sitoayu L., Pertiwi D.A. \& Mulyani E.Y. Kecukupan Zat Gizi Makro, Status Gizi, Stress dan Siklus Menstruasi pada Remaja. J. Gizi Klin. Indonesia. 2017.

10. Notoatmodjo, S. Metodologi Penelitian Kesehatan. Jakarta: Rineka Cipta. 2012.

11. Sugiyono. Metode Penelitian Kuantitatif, Kualitatif dan R\&D. Bandung: Alfabeta. 2009.

12. Adnyani, Gunahariati N.N., dan Triyani N.G.A. Hubungan Status Gizi dengan Siklus Menstruasi pada Remaja Putri Kelas X di SMA PGRI 4 Denpasar. 2013.

13. Hupitoyo. Metode Penelitian Keperawatan dan Teknik Analisa Data. Jakarta: Salemba Medika. 2010.

14. Nunung. Hubungan Status Gizi dengan Siklus Mentruasi pada Remaja Putri di SMAN Bantul Yogyakarta. Skripsi. 2017.

15. Sinha, N.K. Relationship of menstrual disorders with nutritional status of college girls from Bankura District, West Bengal, India. International Journal of Bioassays. 2016. 